\title{
RONDÓ PEDERASTA
}

- MATHEUS GUMÉNIN BARRETO

Virilha: morna e cheirando a vin-

ho e bocas:

ângulos duros, escuros

à espreita nas moitas, mais

ângulos duros entre as qu-

inas

da carne rubra,

o apontar-se do arpão da seta da espada da cr-

uz

do pênis

e as promessas pastoris no terreno de sua carne

os veios sem barco que os navegue

a espada sem braço que a empunhe

as moitas sem lobos que as espreitem ---

eu barco eu braço eu lobo, enf-

im

sagro

o corpo do hom-

em

que submete-se ao homem outro e é

por ele sub-

metido.

MATHEUS GUMÉNIN BARRETO (1992) - poeta e tradutor brasileiro. Nascido em Cuiabá/MT, é pós-graduando da USP, e estudou também na U. de Heidelberg. Traduziu Bertolt Brecht e Ingeborg Bachmann. É autor dos livros de poemas A Máquina de carregar nadas (2017, 7Letras) e Poemas em torno do chão \& Primeiros poemas (2018, no prelo). Foi publicado no Brasil e em Portugal (Escamandro, plaquete do “Vozes, Versos”, Enfermaria 6, Revista Escriva e Diário de Cuiabá; entre outros). É editor do site cultural Ruído Manifesto e integrou o Printemps Littéraire Brésilien 2018 na França e na Bélgica a convite da Sorbonne. 
